\title{
Correction to: Assessment of different anther culture approaches to produce doubled haploids in cucumber (Cucumis sativus L.)
}

\author{
Abouzar Asadi - Alireza Zebarjadi - Mohammad Reza Abdollahi • \\ Jose M. Seguí-Simarro
}

Published online: 3 December 2018

(C) Springer Nature B.V. 2018

Correction to: Euphytica (2018) 214:216

https://doi.org/10.1007/s10681-018-2297-x

The Kurtar et al. (2016) citation along the text was wrongly added by mistake. Instead, it should be Abdollahi et al. (2015).

Therefore, the reference

Kurtar ES, Balkaya A, Kandemir D (2016) Evaluation of haploidization efficiency in winter squash (Cucurbita maxima Duch.) and pumpkin (Cucurbita moschata Duch.) through anther culture. Plant Cell Tissue Organ Cult 127 (2):497-511. https://doi.org/ 10.1007/s11240-016-1074-6

The original article can be found online at https:// doi.org/10.1007/s10681-018-2297-x.

A. Asadi · A. Zebarjadi

Campus of Agriculture and Natural Resources, Razi

University, Kermanshah, Iran

M. R. Abdollahi

Faculty of Agriculture, Bu-Ali Sina University, Hamedan,

Iran

J. M. Seguí-Simarro ( $\square)$

Cell Biology Group - COMAV Institute, Universitat

Politècnica de València, Valencia, Spain

e-mail: seguisim@btc.upv.es should be replaced by:

Abdollahi MR, Darbandi M, Hamidvand Y, Majdi M (2015) The influence of phytohormones, wheat ovary co-culture, and temperature stress on anther culture response of watermelon (Citrullus lanatus L.). Braz J Bot 38: 447-456

Finally, the protocol of Kurtar et al. (2016) summarized in Table 1 is also wrong. Table 1 should now read as follows (the changes are highlighted in bold letters): 


\begin{tabular}{|c|c|c|c|c|c|}
\hline Species & Pretreatment & $\begin{array}{l}\text { Heat } \\
\text { shock }\end{array}$ & Anther culture medium & $\begin{array}{l}\text { Callus/embryo culture } \\
\text { medium }\end{array}$ & Reference \\
\hline \multirow[t]{5}{*}{ Cucumber } & \multirow[t]{5}{*}{$4^{\circ} \mathrm{C}, 2$ days } & \multirow[t]{2}{*}{$\begin{array}{l}32{ }^{\circ} \mathrm{C} \\
1 \text { day }\end{array}$} & $\begin{array}{c}\text { B } 5+0.442,4-\mathrm{D}+0.23 \\
\mathrm{BAP}+8.5 \% \text { sucrose }\end{array}$ & \multirow[t]{2}{*}{$\begin{array}{c}\mathrm{B} 5+0.06 \mathrm{Kin}+0.055 \\
\mathrm{NAA}+3.1 \% \text { sucrose }\end{array}$} & $\begin{array}{l}\text { Ashok Kumar and } \\
\text { Murthy (2004) }\end{array}$ \\
\hline & & & $\begin{array}{l}\mathrm{B} 5+0.4422,4-\mathrm{D}+0.225 \\
\mathrm{BAP}+5 \% \text { sucrose }\end{array}$ & & Xie et al. (2005) \\
\hline & & \multirow[t]{3}{*}{$\begin{array}{c}33{ }^{\circ} \mathrm{C} \\
1 \mathrm{~h}\end{array}$} & $\begin{array}{l}\mathrm{MS}+1 \mathrm{BAP}+1.1 \mathrm{KT}+0.5 \\
2,4-\mathrm{D}+3 \% \text { sucrose }\end{array}$ & $\begin{array}{l}\mathrm{MS}+0.5 \mathrm{BAP}+6 \% \\
\text { sucrose }\end{array}$ & Song et al. (2007) \\
\hline & & & $\begin{array}{l}\mathrm{MS}+0.442,4-\mathrm{D}+0.23 \\
\mathrm{BAP}+0.37 \mathrm{KT}+2.5 \% \\
\text { sucrose }\end{array}$ & $\begin{array}{l}\mathrm{MS}+0.1 \mathrm{NAA}+3 \\
\mathrm{BAP}+3 \% \text { sucrose }\end{array}$ & $\begin{array}{l}\text { Hamidvand et al. } \\
\text { (2013) }\end{array}$ \\
\hline & & & $\begin{array}{l}\mathrm{MS}+0.52,4-\mathrm{D}+1 \\
\mathrm{BAP}+1.15 \mathrm{Kt}+3 \% \text { sucrose }\end{array}$ & $\begin{array}{l}\mathrm{MS}+0.1 \mathrm{NAA}+3 \\
\mathrm{BAP}+3 \% \text { sucrose }\end{array}$ & $\begin{array}{l}\text { Abdollahi et al. } \\
\text { (2016) }\end{array}$ \\
\hline \multirow[t]{3}{*}{ Squash } & \multirow[t]{3}{*}{$4{ }^{\circ} \mathrm{C}, 4$ days } & \multirow[t]{3}{*}{$\begin{array}{l}35^{\circ} \mathrm{C} \\
7 \text { days }\end{array}$} & $\mathrm{MS}+52,4-\mathrm{D}+10 \%$ sucrose & $\begin{array}{l}\mathrm{MS}+0.05 \mathrm{Kin}+0.05 \\
\mathrm{NAA}+3 \% \text { sucrose }\end{array}$ & Shalaby (2006) \\
\hline & & & $\mathrm{MS}+52,4-\mathrm{D}+15 \%$ sucrose & $\begin{array}{l}\mathrm{MS}+0.057 \mathrm{Kin}+0.05 \\
\text { NAA }+15 \% \text { sucrose }\end{array}$ & $\begin{array}{l}\text { Metwally et al. } \\
\text { (1998) }\end{array}$ \\
\hline & & & $\mathrm{MS}+62,4-\mathrm{D}+10 \%$ sucrose & $\begin{array}{l}\mathrm{MS}+0.05 \mathrm{Kin}+0.05 \\
\text { NAA, no sucrose reported }\end{array}$ & $\begin{array}{l}\text { Mohamed and } \\
\text { Refaei (2004) }\end{array}$ \\
\hline Watermelon & $4^{\circ} \mathrm{C}, 2$ days & $\begin{array}{l}32{ }^{\circ} \mathrm{C}, \\
2 \text { days }\end{array}$ & $\begin{array}{l}\mathrm{MS}+3 \mathrm{BAP}+0.1 \mathrm{NAA}+\mathbf{3} \% \\
\text { sucrose }\end{array}$ & $\begin{array}{l}\mathrm{MS}+0.5 \mathrm{BAP}+\mathbf{3} \% \\
\text { sucrose }\end{array}$ & $\begin{array}{l}\text { Abdollahi et al. } \\
\text { (2015) }\end{array}$ \\
\hline $\begin{array}{l}\text { Different } \\
\text { Cucurbita } \\
\text { hybrids }\end{array}$ & $4^{\circ} \mathrm{C}, 2$ days & $\begin{array}{l}35^{\circ} \mathrm{C}, \\
7 \text { days }\end{array}$ & $\mathrm{MS}+12,4-\mathrm{D}+9 \%$ sucrose & $\begin{array}{l}\mathrm{MS}+0.05 \mathrm{Kin}+0.05 \\
\mathrm{NAA}+9 \% \text { sucrose }\end{array}$ & Rakha et al. (2012) \\
\hline
\end{tabular}

